\title{
IDENTIFYING PREDATORY OPEN-ACCESS ACADEMIC JOURNAL PUBLISHERS, IN LIGHT OF THE SOUTH AFRICAN DEPARTMENT OF HIGHER EDUCATION AND TRAINING'S DECISION TO RETROSPECTIVELY DE-ACCREDIT CERTAIN JOURNALS
}

\author{
Marita Carnelley \\ BA LLB LLM PhD \\ Professor of Law, Dean of Research \\ College of Law and Management Studies \\ University of KwaZulu-Natal
}

\section{SUMMARY}

This paper arose out of the retrospective de-accreditation of the journal MJSS by DHET. DHET has always had a clear policy for subsidising research: publication in an accredited journal will lead to the payment of subsidy to the university and in most instances to the academic.

The first part of the paper addresses the issue of online publications, including predatory publications, and what due diligence academics should engage in prior to submitting their research to an unknown journal for publication. In particular, the article sets out the possible criteria that could be used in assessing new journals. Ultimately, the process is fraught with uncertainties and difficulties, as many predatory publishers deliberately set out to scam academics in order to garner financial profits. These problems are illustrated by comparing two online journals: MJSS and PER.

The second part of the article deals with the nature of the decision by DHET to deaccredit MJSS retrospectively - in deciding that it is a potentially predatory journal. It is submitted that DHET could be estopped from denying the truth of its own representation that the MJSS is a scholarly journal. In addition, their decision to retrospectively change their own policy without adequate notice or a proper opportunity for representations, is unconstitutional, unlawful and unfair based on the legitimate expectation of the academics and universities created by the department's policies and practice. In addition, by de-accrediting a journal retrospectively, DHET destabilised its own policy.

In November 2014, the Department of Higher Education and Training (DHET) informed all public universities in South Africa of the removal of, inter alia, the 
Mediterranean Journal of Social Sciences (MJSS) from the International Bibliography of Social Sciences (IBSS) list. The core of the letter reads as follows:

"[F]ollowing recent complaints about one of our accredited journals ... we contacted ProQuest who are the custodians of the International Bibliography of Social Sciences (IBSS).

ProQuest has decided to remove the Mediterranean Journal of Social Sciences, and other journals published by the Mediterranean Centre of Social and Education Research, from all their databases. ProQuest has also undertaken to conduct further analysis and reviews of publishers on the Beall list which are included in their databases to try and identify others with similar problems.

After consultation with the Research Output Evaluation Panel, ${ }^{1}$ the Department of Higher Education and Training will no longer pay subsidy towards articles published in the Mediterranean Journal of Social Sciences. This will be effective from 2013 claims onward. Affected institutions will be contacted individually.

Authors are urged to avoid publishing their works in journals that do not comply with good, scholarly publishing practices, and to report such journals and/or publishers to the DHET. The Department reserves the right to reject any claims for publications published in journals that do not meet the criteria as outlined in the Policy and Procedures for the Measurement of Research Outputs of public higher education institutions, regardless of whether the journal is on an approved list or not."

The problem of predatory publishers ${ }^{2}$ that focus on financial gain rather than good scholarly practices, was further highlighted by the DHET Evaluation Report. ${ }^{3}$ This report encourages academics to consult the various lists of possible predatory publishers and to do some due diligence before publishing their research in one of the journals concerned. ${ }^{4}$ It specifically notes that the DHET policy supercedes the accredited lists. ${ }^{5}$

The 2014 decision to retrospectively de-accredit journals from the 2013 published accredited lists provided for by the 2003 Minister of Education Policies and Procedures, set the proverbial cat amongst the pigeons. It had a direct and negative impact on universities and the academics that published in the MJSS in 2013 and 2014 as the expected subsidies were not paid for these publications. Based on this decision, in late 2014 the Research Office at one of the local public universities (and some other national institutions), made adjustments to the 2013 incentive payouts - resulting in a decrease in the 2013 and 2014 payouts allocated to academics that published in the MJSS. In addition, that Research Office also refers to the Beall's lists, by asking staff:

1 The Research Output Evaluation (ROE) panel refers to a panel of nine Deputy ViceChancellors Research of public higher-educational institutions as well as the Executive Director: Institutional Engagement and Partnership Development (IEPD) of the South African National Research Foundation (NRF) Department of Higher Education Report on the Evaluation of the 2013 Universities' Research Outputs (January 2015) 9 (hereinafter DHET Evaluation Report).

2 In this article, the concept of predatory publishers includes predatory journals, hijacked journals and companies that publish misleading metrics.

DHET Evaluation Report 39.

DHET Evaluation Report 39-40.

DHET Evaluation Report 41. 
"to become familiar with the Beall's List of Predatory Publishers and Journals ... and other sources of information, to ascertain the credibility of publishers and journals ..."

Apart from the reversal of the incentive payouts allocated to the academics based on the articles published in these journals, all page fees paid to the MJSS by the university were reclaimed from the academics. During discussions it was mooted that the performance-management bonuses and promotion of a few individual staff members who were rewarded and promoted in 2014 based, inter alia, on these 2013 de-accredited publications, could potentially be (but were not) reversed as a result of the withdrawal of the journal's accreditation. ${ }^{6}$

From the outset it should be noted that the decision of DHET to no longer pay subsidy for a de-accredited journal that does not meet its requirements per se, is not controversial and should in fact be welcomed. This process ensures the quality of peer-review subsidised research. Previously, however, universities were given advanced notice of possible de-accreditation.

The retrospective nature of the decision is contentious in light of the legal concept of estoppel, as well as the constitutional requirement that all administrative actions be lawful, reasonable and procedurally fair. This considered, the aim of this article - in addition to foregrounding the journal-deaccreditation issue for South African academics - is to determine whether the retrospective nature of the decision can withstand legal and constitutional scrutiny. ${ }^{8}$ The discussion takes place within a broader international discussion of online and predatory publishers and journals - with specific reference to Beall's lists, the DHET policy documents, and also its lists of accredited journals.

\section{POLICY AND PROCEDURES FOR MEASUREMENT OF RESEARCH OUTPUTS OF PUBLIC HIGHER EDUCATION INSTITUTIONS AND ACCREDITED LISTS IN SOUTH AFRICA}

In South Africa, the governmental policy and subsidy system are set out in the June 2003 Ministry of Education Policy and Procedures for Measurement of Research Output of Public Higher Education Institutions, ${ }^{9}$ which is to be replaced by the 2015 DHET Research Outputs Policy in January 2016. The

$6 \quad$ This local public university's performance bonuses and promotions directly depend on, inter alia, a certain minimum number of accredited publications appearing in the year(s) leading up to the assessment (Generic Key Performance Areas for Academic Staff (2013), as read with the Academic Promotions Policies \& Guidelines (2011 and 2013 respectively).

7 At the end of the DHET list of accredited journals, a list appears of journals that have been reviewed and removed from the list as well as the reason for the removal.

8 The discussion in this article is limited to journal articles.

9 DHET and ASSAF currently implements this policy. The policy is a result of the ASSAF Report on a Strategic Approach to Research Publishing in South Africa (2006) vii-xi that highlighted the need for an increase in quality of South African research output through proper peer-review and post-publication evaluation of journals as well as the need to embrace technology. 
purpose of these policies is to encourage quality research. ${ }^{10}$ DHET does not measure or intend to measure all output - but rather makes use of proxies to determine quality. Research is defined as "original, systematic investigation undertaken in order to gain new knowledge and understanding". Peer evaluation is regarded as being essential to ensure the quality of all research. ${ }^{11}$

For the purpose of DHET subsidy, only specific research outputs are recognised, including journals appearing in the indices of the Institute of Scientific Information (ISI); the International Bibliography of Social Sciences (IBSS); and the Department of Education's (DoE) Index of Approved South African Journals. It is unclear why DHET elected to accredit these indices as accepted scholarly journals or how these indices are compiled. The Department annually issues the official lists of journals for each of the above indices for each reporting year. ${ }^{12}$ The Research Output Policy notes that to "ensure stability of the system, approved lists will not change drastically from year to year or in a way that would cause confusion". ${ }^{13}$ DHET seems to favour international journals as their South African list comprises less than $2 \%$ of the total number of accredited titles, and they emphasise that these have limited international exposure:

"With South Africa having a small pool of researchers who know each other and well-established researchers in most cases have collaboration links, whether in the past or present; this raises the question about quality and whether or not biased peer-review practices exist in local journals.

Both the existing and 2016 policies make provision for the removal of journals from the approved list of South African journals where criteria are no longer met, but not for the removal from the IBSS and ISI lists. Although the DHET Research Output Policy notes that "[i]nstitutions should safeguard against predatory journals whose main purpose is financial gain rather than the quality of research", ${ }^{15}$ it does not provide for the retrospective removal from any list.

These lists are heavily relied upon by academics when deciding where to publish their research. This is especially true for institutions that link DHETaccredited research output to research-productivity incentives, performance management, promotions, and merit awards. With the pressure on academics to publish more widely - both nationally and internationally - it is inevitable that new and lesser-known journals are sought for publication.

Government policies on subsidising the research output of higher education institutions have a direct impact on the behaviour of researchers. Universities and academics align their actions to the policy - in time resulting in the policy

10 DHET Research Output Policy 2.2; Ministry of Education Measurement of Research Output 3.

11 DHET Research Output Policy 2.4; Ministry of Education Measurement of Research Output 3-4.

12 DHET Research Output Policy 5.2; Ministry of Education Measurement of Research Output 10.

13 DHET Research Output Policy 5.2.

14 DHET Evaluation Report 12.

15 DHET Research Output Policy 5.3. 
meeting its intended goal of increasing research output. ${ }^{16}$ The DHET Research Output Policy, however, now warns of predatory journals and this will presumably result in South African academics being more selective about where they publish in future. The retrospective decision about the MJSS, has in fact created confusion and destabilised the system. The threat of retrospective de-accreditation of journals from the accredited lists will result in academics reverting to publishing in national journals they know meet the scholarly criteria and where the editors and editorial boards are recognised rather than unknown international journals. This will be counterproductive and will defeat the purpose of the stated DHET Research Output Policy, which is to avoid academic "national inbreeding".

The bottom line remains that academics will have to take more responsibility with regard to the self-assessment of the targeted journals. Some background to the problem is warranted.

\section{OPEN ACCESS, PREDATORY JOURNALS, AND BEALL'S LISTS}

\section{Open access}

During the past 15 years, there has been an exponential growth of openaccess publications internationally. These publications are available digitally often free of charge and free from most copyright and licensing restrictions. ${ }^{17}$ The growth was borne out of technical developments, the need for and ability to provide increased access to available scholarship worldwide, ${ }^{18}$ and the potential for increased citing rates, ${ }^{19}$ combined with the expense of subscription databases ${ }^{20}$ and the movement championing that public-funded research should be freely available to the public. ${ }^{21}$ Some major funders have recently decided to only award grants on condition of open-access publication of the resulting research. ${ }^{22}$ Both DHET and ASSAF in South Africa support online publications - including the Scientific Electronic Library Online (SciELO). ${ }^{23}$ The Registry of Open Access Repositories Mandatory Archiving

16 Madue The Effect of the Research Component of the South African Higher Education Subsidy Formula on Knowledge Production: 2001-2006 (DAdmin thesis UNISA) $2011 \mathrm{i}$.

17 Czerniewicz and Goodier "Open Access in South Africa: A Case Study and Reflections" 2014 South African Journal of Science 1; Smart "Open Access Journals - It's Not All About Free" in Smart, Maissonneuve and Polderman (eds) Science Editors' Handbook (2013) 1.

18 Perry "Scholarly Journals Identifying Potentially Predatory Publishers: The Case of Open Access" 2014 http://cnx.org/content/m49845/1.1/ 4 (accessed 2015-04-22).

19 Smart in Smart et al (eds) Science Editors' Handbook 3-4.

20 This is especially problematic in a country like South Africa - with an unfavourable R/\$ exchange rate.

21 Czerniewicz and Goodier 2014 South African Journal of Science 1, 3; Eisen "Beall's litter' It is NOT Junk" 2013 http://www.michaeleisen.org/blog/?p=1500/ (accessed 2015-04-22).

22 Czerniewicz and Goodier 2014 South African Journal of Science 2; Smart in Smart et al (eds) Science Editors' Handbook 2.

23 ASSAF Report on Grouped Peer Review 18: "SciELO will become an important tool for the Department of Higher Education and Training to consider articles for subsidy purposes." 
Policies (ROARMAP) is useful in this regard, as the South African National Research Foundation (NRF) is listed in ROARMAP. ${ }^{24}$

With regard to open-access publishers and journals, there are various types of open access, ${ }^{25}$ gold and green being the most significant. Gold open access makes journal articles available at a fee, mostly under licence, ${ }^{26}$ and green open access allows authors to deposit their articles within an open repository. ${ }^{27}$

"[T]he policy shift to open access has seen an explosion in vanity publishers and 'predatory' journals which assure scholars of publication at a cost, regardless of peer review or quality."

Dubious publication ethics are not new ${ }^{29}$ and various "sting operations" have been used, ${ }^{30}$ where non-scholarly, plagiarised or computer-generated nonsense was sent to online journals for publication to test their scholarly checks and balances. Many of these bogus articles were accepted for publication, showing that many of these online publishers and journals, including journals published by reputable publishing houses, such as Sage, Elsevier and Wolters Kluwer, ${ }^{31}$ did not always follow proper peer-review processes and did not always meet general good scholarly standards. ${ }^{32}$

Academics obviously want to avoid publishing their research in nonscholarly journals that may damage their reputation. ${ }^{3}$

24 ROARMAP Registry of Open Access Repositories Mandatory Archiving Policies: "ROARMAP is a searchable international registry charting the growth of open access mandates adopted by universities, research institutions and research funders that require their researchers to provide open access to their peer-reviewed research article output by depositing it in an open access repository."

25 Open access is not limited to open-access journals and publishers, as institutions can embark on a strategy to provide open-access repositories for their academics (Czerniewicz and Goodier 2014 South African Journal of Science 8; and Smart in Smart et al (eds) Science Editors' Handbook 2). This possibility falls outside the scope of this article.

26 An example is the Creative Commons BY licence (www.creativecommons.org). See, in general, Eisen http://www.michaeleisen.org/blog/?p=1500/ 11-13; and Bohannon "Who's Afraid of Peer Review?" 2013 Science 6064.

27 Czerniewicz and Goodier 2014 South African Journal of Science 1. Smart in Smart et al (eds) Science Editors' Handbook 4, also refers to libre open access, which refers to the scenario where the journal makes its articles available free of charge, but under a licence that is more restrictive than the Creative Commons BY licence.

28 Czerniewicz and Goodier 2014 South African Journal of Science 6.

29 Wiwanitkit "Publication Ethics: Many Facets, Collaboration Required" 2013 Iranian Journal of Basic Medical Sciences 664.

30 Bohannon 2013 Science 60-65.

31 Bohannon 2013 Science 65.

32 Butler-Adam "Dealing with 'Open-access' Demons" 2014 South African Journal of Science 1; and Bohannon 2013 Science 61. Examples include deceitful payment requirements, spam requests for unsuitable reviewers, or unauthorised use of academics on editorial boards (Bohannon 2013 Science 61; Beaubien and Eckard "Addressing Faculty Publishing Concerns with Open Access Journal Quality Indicators" 2014 Journal of Librarianship and Scholarly Communication eP1133 12 ; and Perry http://cnx.org/content/m49845/1.1/2).

33 Eisen http://www.michaeleisen.org/blog/?p=1500/ 6; and Perry http://cnx.org/content/m49845 /1.1/ 2 . 


\section{Good, scholarly publishing practices}

Whatever type of open access is applicable, reliable scientific scholarly journals have some common features such as quality, integrity-driven research, permanent availability, genuine peer review, editors and an editorial board with acknowledged associations, and transparent pricing. ${ }^{34}$ There are existing best practices that editors, journals and publishers can align themselves to. In South Africa ASSAF's 2008 National Code of Best Practice in Editorial Discretion and Peer Review for South African Scholarly Journals contains guidelines to editors, focused mainly on the integrity of the research and the indispensable nature of peer-review. Internationally, the Committee on Publishing Ethics (COPE) 2011 Ethics Code of Conduct and Best Practices Guidelines for Journal Editors and its 16 Principles for Transparent and Best Practices go wider in its guidelines - to include numerous other criteria that have been accepted widely. ${ }^{36}$

\section{How to determine if a journal is possibly predatory?}

\section{Introduction}

Prior to the MJSS saga, the route South African academics followed in order to determine the scholarliness of a journal, was to consult the three DHET accredited lists. ${ }^{37}$ After all, the lists come from an official source, and no journal on these lists had previously been de-accredited retrospectively. In addition, there is a general lack of knowledge about the increase in predatory publications. Being on an accredited list is, however, no guarantee of scholarliness - especially in light of the new DHET Research Output Policy, and thus it is insufficient for South African academics to solely rely on these accredited lists.

For an academic wanting to determine which journals are predatory is not necessarily easy - especially in this era of online publications. In addition, the peer-review process is and always has been rather opaque. ${ }^{38}$ Adding to the problem is that predatory journals attempt to trick possible authors into believing that their publications are scholarly and reputable. ${ }^{39}$

Although many online journals are predatory, not all are, and also, all predatory journals are not online. ${ }^{40}$ The fact that a journal is published online, is open access or has a financial model requiring payment - does not

34 Sohail "Of Predatory Publishers and Spurious Impact Factor" 2014 Journal of the College of Physicians and Surgeons Pakistan 537.

35 Beall bases his recommendations on the COPE's Code of Conduct and 16 Principles. See, also, the guidelines of the World Association of Medical Editors (http://www.wame.org); Wilson "Librarian vs (Open Access) Predator: An Interview with Jeffrey Beall" 2013 Serials Review 125 126; and Clark "How to Avoid Predatory Journals - A Five Point Plan" 2015 British Medical Journal 1.

${ }^{36}$ See discussion below.

37 The presumption was based on the belief that DHET applied its mind to the choice of lists, journals and publishers to accredit.

38 ASSAF Report on Grouped Peer Review 9

39 Perry http://cnx.org/content/m49845/1.1/2.

40 Bivens-Tatum "Anti-OA and the Rhetoric of Reaction" 2013 Academic Librarian 1. 
necessarily determine the quality of the scholarship of the journal. ${ }^{41}$ Online publishers - like their traditional equivalents - require some funding inter alia for the process of peer-review, editing, website maintenance and archiving. ${ }^{42}$

To determine whether a publisher or a journal is predatory, the landscape is more complex and requires additional effort. A good starting point would be the so-called white and black lists.

\section{White and black lists}

Two types of lists have been developed to assist academics - the so-called white and black lists. White lists attempt to include those journals that adhere to good scholarly practices and the black lists cover the opposite group.

The white lists include the Directory of Open Access Journals (DOAJ) as supported by the Open Access Scholarly Publishing Association (OASPA). ${ }^{43}$ DOAJ is an attempt to index online-access journals that meet their criteria for good scholarly publications. ${ }^{44}$ These lists are not always reliable, as they too have had to remove journals and publishers from their lists that turned out to observe unacceptable scholarly practices. ${ }^{45}$

The black lists include potentially non-scholarly publications. Beall's lists of potentially predatory publishers and journals are the most well-known: ${ }^{46}$

[Beall] deserves credit for almost single-handedly raising awareness about predatory publishers trying to take advantage of the rise of open-access $-a$ problem nobody else was noticing let alone trying to do something about.

Beall's lists are available online. The set of lists is in its $5^{\text {th }}$ release and is being continuously updated. The lists attempt to highlight the problem of predatory journals by warning academics against "potential, possible or probable" predatory publishers and journals. ${ }^{48}$ There are four individual lists.

41 Haug "The Downside of Open-access Publishing" 2013 New England Journal of Medicine 791.

42 Although there are no article publishing and manual distribution costs, the other costs remain.

43 The mission of OASPA is to support and represent the interests of Open Access journals and book publishers globally - in all scientific, technical and scholarly disciplines.

44 Smart in Smart et al (eds) Science Editors' Handbook 1. DOAJ can be found at https://doaj.org. OASPA is one organisation that aims to identify journals and publishers that meet good scholarly practices (Beaubien and Eckard 2014 Journal of Librarianship and Scholarly Communication 2; Perry http://cnx.org/content/ m49845/1.1/ 3; Berger and Cirasella "Beyond Beall's List. Better Understanding Predatory Publishers" 2015 College \& Research Libraries News 132 134; and Bohannon 2013 Science 61).

45 Clark 2015 British Medical Journal 1; Berger and Cirasella 2015 College \& Research Libraries News 133; and Anderson "Housecleaning at the DOAJ" The Scholarly Kitchen 2014 http://scholarlykitchen.sspnet.org/2014/08/14/housecleaning-at-the-DOAJ/ 2 (accessed 201504-22). Bohannon 2013 Science 64 exposed some DOAJ journals that did not adhere to the good scholarly practices they prima facie prescribed to.

46 The author could not obtain any other list of predatory journals apart from Beall's - although tertiary institutions may have internal lists of journals that they advise their academics to avoid.

47 Eisen http://www.michaeleisen.org/blog/?p=1500/ 16.

48 Beall Scholarly Open Access. List of Publishers. Beall's List: Potential, Possible, or Probable Predatory Scholarly Open-access Publishers 2015 http://scholarlyyoa.com/ publishers (accessed 2015-04-22); and Beall Scholarly Open Access. List of Standalone Journals: 
In 2015, Beall's ${ }^{49}$ lists of publishers includes 693 potentially predatory publishers. The increase in the number of predatory publishers has been exponential: from 18 and 23 in 2011 and 2012 respectively, the numbers jumped to 225 in 2013 , and doubling to 477 in 2014 . The potentially predatory journals increased from 125 in 2013, to 303 in 2014 and then to 507 in 2015. In 2015, Beall published two additional lists: the Misleading Metrics list (26 companies listed) and the Hijacked Journal list (30 journals listed):

"The Misleading metrics list includes companies that 'calculate' and publish counterfeit impact factors (or some similar measure) to publishers, metrics the publishers then use in their websites and spam email to trick scholars into thinking their journals have legitimate impact factors.

The Hijacked journals list includes journals that use names similar to, or are the same as, respected journals. ${ }^{51}$

Beall ${ }^{52}$ uses almost 50 criteria - based mainly on the COPE Code of Conduct - for determining whether a publisher or a journal should be added to the potentially predatory lists. ${ }^{53}$ Apart from evidence of the lack of sufficient peer review, there are six other major indicators to assess whether a publisher or a journal could be regarded as predatory: ${ }^{54}$

"[T]he journal does not identify a formal editorial/review board; the publisher has no policies or practices for digital preservation; the publisher begins operations with a large fleet of journals, often using a template to quickly create each journal's home page; the publisher provides insufficient information or hides information about author fees, offering to publish an author's paper and later sending a previously-undisclosed invoice; the name of a journal does not adequately reflect its origin; and the journal falsely claims to have an impact factor, or uses some made up measure (e.g. view factor), feigning international standing."

Beall's lists have gained traction and Bohannon ${ }^{55}$ in his sting operation, noted that Beall is "good at spotting publishers with poor quality control". ${ }^{56}$ As

Potential, Possible, or Probable Predatory Scholarly Open-access Journals 2015 http://scholarlyyoa.com/individual-journals (accessed 2015-04-22).

49 Beall Scholarly Open Access. Beall's List of Predatory Publishers 2015 http://scholarlyoa. com/2015/01/02/bealls-list-of-predatory-publishers-2015/ (accessed 2015-04-22).

50 Beall Scholarly Open Access. Misleading Metrics 2015 http://scholarlyyoa.com/otherpages/misleading-metrics (accessed 2015-04-22).

51 Beall Scholarly Open Access. Hijacked Journals $2015 \mathrm{http} / / /$ scholarlyyoa.com/otherpages/hijacked-journals (accessed 2015-04-22). See, also, Tin et al "Predatory and Fake Scientific Journals/publishers - A Global Outbreak with Rising Trend: A Review" 2014 Geographica Pannonica 69-81.

52 Beall Scholarly Open Access. Criteria for Determining Predatory Open-access Publishers 2015 https://scholarlyoa.files.wordpress.com/2015/01/criteria-2015.pdf (accessed 2015-0422). His process is set out on the website and his decisions are based on a variety of sources of information.

53 Beall notes in his blog of 2015-01-05 http://scholarlyoa.com/2015/01/02/bealls-list-ofpredatory-publishers-2015/: "I cannot figure out a way to stop predatory publishing, so I am trying to alert as many people as I can so they will not be victimized by the corrupt practices of questionable publishers."

54 Beall Six Ways to Identify Predatory OA Journal Publishers 2013 http://www. slideshare.net/TAAAuthors/6-waysoa-journalbeall-slideshare (accessed 2015-04-22).

55 Bohannon 2013 Science 64.

56 Tin et al 2014 Geographica Pannonica 69, recommends that Beall's lists should be consulted each time - before an academic submits an article for publication. 
an aside, it should be noted that there are still publishers on the accredited IBSS list that are regarded as being possibly predatory by Beall, such as the Clute Institute's Journal of Applied Business Research and the International Business and Economics Research Journal. ${ }^{5}$

Although Beall has been instrumental in identifying potentially predatory publishers and journals, his efforts are not appreciated by all - least of all by those included on his lists. His detractors highlight the limitations of his methodology when drafting his lists, the lack of nuancing of the criteria, as well as his personal dislike of open-access journals. ${ }^{58}$

There is, however, agreement that there is a need for a list of predatory publishers. Even one of Beall's fiercest critics, the Clute Institute, ${ }^{59}$ acknowledges the need - but would prefer one created by an "impartial body of scholarly-conscious individuals whose main goal is to protect the academic community from publishers with a track record of misconduct ..." However, in the absence of another reliable, generally acceptable list, reliance on the Beall lists seems inevitable - as is clear from the DHET letter quoted previously.

\section{Duty on academics to do due diligence}

For academics to avoid publishing in predatory journals - which could harm their career prospects and stigmatise their research ${ }^{60}$ - there is thus a need to find methods to identify and assess journals and publishers. ${ }^{61}$

From a broader perspective it has been argued that there is a need for a new, broader discourse about research in the current century ${ }^{62}$ and that

57 It is submitted that this would make these journals potentially problematic, as DHET requested ProQuest to investigate other journals on the Beall's lists - they may follow in the footsteps of the MJSS and be de-accredited.

58 Clute Institute What are Fellow Researchers Saying about Jeffrey Beall's Predatory List? 2014 http://www.cluteinstitute.com/2014/12/what-are-fellow-researchers-saying-about-jeffreybealls-predatory-list/ (accessed 2015-04-22); Eisen http://www.michaeleisen.org/blog/? $\mathrm{p}=1500 / 1$; Fiebert $A$ Look at Open Access Publication and a Specific Critique of Beall's List of "So Called" Predatory Journals $2014 \mathrm{http}: / /$ www.academia.edu/7641635/A Look at Open_Access_Publications_and_a_Specific_Critique_of_Bealls_list_of_Predatory_Journals/ (accessed 2015-04-22). See, also, Beaubien and Eckard 2014 Journal of Librarianship and Scholarly Communication 3). Voices of opposition also come from the publishing industry (Esposito Parting Company with Jeffrey Beall 2013 http://scholarlykitchen.sspnet. org/2013/12/16/partingcompany-with-jeffrey-beall/ (accessed 2015-04-22); Multidisciplinary Digital Publishing Institute Response to Mr Jeffrey Beall's repeated attacks on MDPI 14 April 2014 http://www.mdpi.com/about/announcements/534 534 (accessed 2015-04-22); Ludlum How Mustang Got its Start undated http://mustangjournals.com/ The Mustang Story.pdf (accessed 2015-04-22); EditorJCCR notes that Beall is acting in an unethical manner, by blackmailing small publishers - as, for a fee of US $\$ 5000$, Beall will remove a publisher's name from his list (EditorJCCR "Open Access Publishing - USD5000 is Enough to Remove your Publisher's Name from Beall's List" 2012 http://editorjccr. wordpress.com/2012/12/ (accessed 2015-04-22)). This turned out to be a scam e-mail, which was not sent by Beall (Wilson 2013 Serials Review 126).

59 The Clute Institution is a publisher on Beall's lists. Beall describe the organisation as "a scholarly vanity press" (Beall Scholarly Open Access. Bogus "Centre" Provides Quick, Easy and Cheap Publishing 2015 http://scholarlyoa.com/2014/09/16/bogus-centre-provides-quickand-cheap-publishing/ (accessed 2015-04-22).

60 Perry http://cnx.org/content/m49845/1.1/ 2 .

61 Tin et al 2013 Geographica Pannonica 74. 
Government and academics should engage directly about research policies and funding. ${ }^{63}$ In addition, collaboration between academics and publishers should be more robust, in order to strengthen the interests of academia. ${ }^{64}$

Apart from these open discussions, the education of academics is paramount. ${ }^{65}$ For an academic to make an informed decision about submission to a journal, some due diligence has to be done ${ }^{66}$ and it requires a targeted approach. ${ }^{67}$ Academics should refer to the DHET-accredited and white and black lists as a starting point ${ }^{68}$ - even if they are not always $100 \%$ reliable. Academics should be especially wary if an unknown journal is targeted for possible publication. ${ }^{69}$ The academic should evaluate the journal and the contents of previously published and archived articles on a case-bycase basis, in terms of set criteria. ${ }^{70}$ Most authors suggest that the evaluation should be done in terms of criteria similar to those used by COPE (and Beall). ${ }^{71}$ These include: consideration of the respectability of editorial-board members, ${ }^{72}$ digital preservation policies, whether the journal is part of a large fleet of journals with template websites, whether the fee structure is clear, whether the name of the journal reflects its origins, and whether the impact factor is correctly reflected. ${ }^{73}$

Apart from these six issues, academics should ask themselves the following additional questions: Is there a clear peer-review process for submitted articles ${ }^{74}$ and what is the actual experience of the author? What is the focus area of the journal and does it link disciplines that do not traditionally fit together? ${ }^{75}$ Have any of the discipline specialists from reputable institutions, read, reviewed or published in the journal $?^{76}$ Is the journal or the publisher a member of a recognised and a professional organisation committed to best practices? ${ }^{77}$ Is the journal indexed? ${ }^{78}$ Does the journal have regular serial

62 Czerniewicz and Goodier 2014 South African Journal of Science 8; and Tin et al 2013 Geographica Pannonica 74.

63 Czerniewicz and Goodier 2014 South African Journal of Science 8.

64 Ibid.

65 Beaubien and Eckard 2014 Journal of Librarianship and Scholarly Communication 7.

66 Perry http://cnx.org/content/m49845/1.1/2.

67 Banerjee "The Publication Rat Race: Who Will Bell the Cat?" 2013 Medical Journal of Dr DY Patil University 219.

68 DHET Evaluation Report 39-40.

69 Czerniewicz and Goodier 2014 South African Journal of Science 8.

70 Beaubien and Eckard 2014 Journal of Librarianship and Scholarly Communication 4; and Perry http://cnx.org/content/m49845/1.1/2.

71 Tin et al 2013 Geographica Pannonica 73-74; Sohail 2014 Journal of the College of Physicians and Surgeons Pakistan 537; Perry http://cnx.org/content/m49845/1.1/ 3; and Beaubien and Eckard recommend that both positive and negative criteria should be included (Beaubien and Eckard 2014 Journal of Librarianship and Scholarly Communication 5).

72 Tin et al 2013 Geographica Pannonica 74; and Perry http://cnx.org/content/m49845/1.1/2.

73 See, also, Perry http://cnx.org/content/m49845/1.1/2.

74 Perry http://cnx.org/content/m49845/1.1/2.

75 Beall https://scholarlyoa.files.wordpress.com/2015/01/criteria-2015.pdf.

76 Tin et al 2013 Geographica Pannonica 74.

77 Perry http://cnx.org/content/m49845/1.1/2.

78 Fiebert http://www.academia.edu/7641635/A Look at Open Access Publications and a SpecificCritique_of_Bealls_list_of_Predatory_Journals/ $\overline{4}$. Although this may also be problematic as the companies compiling the databases compete for journal-inclusion numbers, resulting in their erring on the side of inclusion of journals rather than rejecting their 
publications and accepted industry references, such as ISSN numbers? ${ }^{79}$ Does the journal protect its own copyright, or does this remain with the author? ${ }^{80}$

This combination of criteria should give an academic some indication of whether the publisher or journal is one of scholarly repute. If doubts remain proceeding with extreme caution is recommended.

Using the criteria mentioned above to assess unknown journals, but without assessing any of the actual published articles, ${ }^{81}$ the author roughly tested whether a young academic - doing some due diligence - would have been able to determine whether that online journal concerned is possibly predatory or not. Two journals were considered, ${ }^{82}$ the MJSS and PER: ${ }^{83}$

\begin{tabular}{|c|c|c|c|}
\hline & & MJSS & $P E R$ \\
\hline 1 & $\begin{array}{l}\text { On DHET- } \\
\text { accredited list? }\end{array}$ & $\begin{array}{l}\text { Removed from IBSS in } \\
\text { November } 2014\end{array}$ & Yes - IBSS \\
\hline 2 & On white list? & No & Yes - DOAJ \\
\hline 3 & On Beall's lists? & From September 2014 & No \\
\hline 4 & $\begin{array}{l}\text { Is there a clear } \\
\text { prima facie peer- } \\
\text { review process for } \\
\text { submitted articles? } \\
\text { Is the actual peer- } \\
\text { review process a } \\
\text { sham? }\end{array}$ & $\begin{array}{l}\text { Yes, with a promise of } \\
\text { feedback within 3-4 weeks. } \\
\text { Personal peer-review } \\
\text { experiences unknown. }\end{array}$ & $\begin{array}{l}\text { Yes. No, as the author } \\
\text { has experience both as } \\
\text { an author and reviewer, } \\
\text { and the process is } \\
\text { robust. }\end{array}$ \\
\hline 5 & $\begin{array}{l}\text { Publication's } \\
\text { discipline focus } \\
\text { areas }\end{array}$ & $\begin{array}{l}\text { All social science fields: } \\
\text { Mediterranean and World } \\
\text { Culture, Sociology, } \\
\text { Philosophy, Linguistics, } \\
\text { Literature, Education, } \\
\text { History, History of Religion, } \\
\text { Anthropology, Statistics, } \\
\text { Politics, Laws, Psychology } \\
\text { and Economics. }\end{array}$ & $\begin{array}{l}\text { South African and } \\
\text { comparative studies on } \\
\text { development law and } \\
\text { constitutionalism. }\end{array}$ \\
\hline 6 & $\begin{array}{l}\text { Formal editorial } \\
\text { board? }\end{array}$ & Yes & Yes \\
\hline 7 & Are the editor and & Some, yes, with links to CVs, & Yes \\
\hline
\end{tabular}

inclusion (Clark 2015 British Medical Journal 2-3; Wilson 2013 Serials Review 127; and Tin et al 2013 Geographica Pannonica 74).

79 Tin et al 2013 Geographica Pannonica 74.

80 Czerniewicz and Goodier 2014 South African Journal of Science 8. As an aside, the copyright issues of academics publishing in international journals should be noted in light of the SCA judgment of Oilwell (Pty) Ltd v Protec International Ltd (295/10) [2011] ZASCA 29 (18 March 2011) as discussed by Wild "Copyright issues dog academics" (31 July - 6 August 2015) Mail and Guardian 28. This issue falls outside the scope of this article.

81 This decision was informed by the assumption that most young academics would not feel able to assess the articles, and because the author is not an expert in the wide subject fields of the MJSS.

82 The process has two limitations: one, the actual peer-review process was not considered, and two, the quality of the articles in the journals was not assessed.

83 The reason for the choice of PER is because it was the first South African electronic law journal. 


\begin{tabular}{|c|c|c|c|}
\hline & & MJSS & PER \\
\hline & $\begin{array}{l}\text { members of the } \\
\text { editorial board } \\
\text { respectable and } \\
\text { known scholars? }\end{array}$ & $\begin{array}{l}\text { although there are some } \\
\text { obvious mistakes. }{ }^{84} \text { South } \\
\text { African academics on the } \\
\text { board are both fairly young } \\
\text { and recently PhD qualified. } \\
\text { The three journals of the } \\
\text { publisher have the same } \\
\text { editorial board. }\end{array}$ & \\
\hline 8 & $\begin{array}{l}\text { Have any of the } \\
\text { discipline } \\
\text { specialists from } \\
\text { reputable } \\
\text { institutions, read, } \\
\text { reviewed or } \\
\text { published in the } \\
\text { journal? }\end{array}$ & $\begin{array}{l}\text { Known academics published } \\
\text { in MJSS (including } \\
\text { professors from Wits and } \\
\text { UKZN), but none has } \\
\text { reviewed. }\end{array}$ & Yes \\
\hline 9 & $\begin{array}{l}\text { Does the journal or } \\
\text { the publisher } \\
\text { subscribe to an } \\
\text { organisation } \\
\text { committed to best } \\
\text { practices? }\end{array}$ & Yes - COPE & Yes - ASSAF \\
\hline 10 & $\begin{array}{l}\text { Does the journal } \\
\text { have regular } \\
\text { publications and } \\
\text { accepted industry } \\
\text { references such as } \\
\text { ISSN numbers? }\end{array}$ & $\begin{array}{l}\text { Yes, } 6 \text { issues per annum and } \\
\text { numerous special issues } \\
\text { with large numbers of } \\
\text { articles per issue. ISSN: } \\
2039-9340 \text { (print) ISSN } \\
2039-2117 \text { (online) }\end{array}$ & $\begin{array}{l}\text { Yes, } 6 \text { issues per } \\
\text { annum, no special } \\
\text { issues. } \\
\text { ISSN: } 1727-3781\end{array}$ \\
\hline 11 & $\begin{array}{l}\text { Is the journal } \\
\text { indexed? }\end{array}$ & Yes - Scopus & Yes - DOAJ \\
\hline 12 & $\begin{array}{l}\text { Is the impact factor } \\
\text { of the journal } \\
\text { reflected? [The } \\
\text { correctness hereof } \\
\text { was not } \\
\text { established]. }\end{array}$ & $\begin{array}{l}0.377 \text { (2013: GIF - Global } \\
\text { Impact Factor http://global } \\
\text { impactfactor.com) } \\
6.44 \text { (2012: Index } \\
\text { Copernicus } \\
\text { en.indexcopernicus.com }\end{array}$ & $\begin{array}{l}0.01 \text { (Washington \& } \\
\text { Lee University School } \\
\text { of Law: Law Journals: } \\
\text { Submissions 2006- } \\
2013 \\
\text { http://lawlib.wlu.edu/LJ) }\end{array}$ \\
\hline 13 & $\begin{array}{l}\text { Does the journal } \\
\text { protect its own } \\
\text { copyright or does it } \\
\text { remain with the } \\
\text { author? }\end{array}$ & Publisher copyright & Author copyright \\
\hline 14 & $\begin{array}{l}\text { Prima facie } \\
\text { archiving/digital } \\
\text { preservation? }\end{array}$ & Yes & Yes \\
\hline 15 & $\begin{array}{l}\text { Clear indication that } \\
\text { payment is } \\
\text { required? }\end{array}$ & $\begin{array}{l}\text { Yes and discount for multiple } \\
\text { submissions per journal } \\
\text { (although this was amended } \\
\text { in 2015) }\end{array}$ & $\begin{array}{l}\text { Yes - minimal page } \\
\text { fees from } 2015 \text { (R45 } \\
\text { per page) }\end{array}$ \\
\hline 16 & $\begin{array}{l}\text { Did publisher begin } \\
\text { operations with a } \\
\text { large fleet of } \\
\text { journals? }\end{array}$ & $\begin{array}{l}\text { MCSER (Mediterranean } \\
\text { Centre of Social and } \\
\text { Educational Research) } \\
\text { started in } 2010 \text { with MJSS } \\
\text { and added two additional }\end{array}$ & No \\
\hline
\end{tabular}

${ }_{84} \mathrm{Eg}$, UKZN is listed as a university based in Zimbabwe - and not South Africa. 


\begin{tabular}{|c|c|c|c|}
\hline & & MJSS & PER \\
\hline & & $\begin{array}{l}\text { journals in } 2011 \text { and } 2012 \\
\text { (Journal of Educational and } \\
\text { Social Research and } \\
\text { Academic Journal of } \\
\text { Interdisciplinary Studies) }\end{array}$ & \\
\hline 17 & $\begin{array}{l}\text { Is the homepage of } \\
\text { the publisher's } \\
\text { journals based on a } \\
\text { template? }\end{array}$ & Yes & No \\
\hline 18 & $\begin{array}{l}\text { Does the name of } \\
\text { the journal reflect } \\
\text { the origin? }\end{array}$ & $\begin{array}{l}\text { Prima facie it does, although } \\
\text { the journals were only } \\
\text { published in collaboration } \\
\text { with the Sapienza University } \\
\text { and the Research Centre } \\
\text { CEMAS (Rome) in } 2010-11 \text {. } \\
\text { Beall found it to actually be } \\
\text { an Albanian operation. }\end{array}$ & Yes \\
\hline
\end{tabular}

Based on the post-September 2014 information, the MJSS would be highlighted as possibly predatory - as it no longer appears on the IBSS list but on Beall's lists of predatory journals. However, before its appearance on the Beall's lists, the answer would not have been so clear-cut - especially for younger academics. The journal appears prima facie to be scholarly. However, what could have raised red flags are: the lack of publication focus; the fact that Sapienza University is no longer involved; the publisher commenced operations recently with three journals; the website is based on a template; the number of articles per issue and the discount for multiple publications per volume; the short peer-review times; and the combined editorial board of the three journals that included only recently PhD-qualified South African academics, and with incorrect data. It is unlikely that a young academic would have picked up on all these issues - especially because senior South African academics have published in the journal. However, a seasoned academic should have regarded the MJSS turnaround time as being too good to be true - especially when it became clear from personal and other feedback that the peer-review process of the journal is not always rigorous. In addition, the number of articles per volume and the discount price for more than one article per volume clearly indicated that the journal placed a premium on quantity.

The assessment of the information on PER would be easier to check. The 2014 ASSAF Report on Grouped Peer Review in Law and Related Legal Fields evaluated the journal as favourable and also recommended that it keeps its accreditation. ${ }^{85}$ In addition, as the academics involved are wellknown South African scholars, the journal is limited to a specific, narrow focus area. The journal is thus known to the peers of these academics, with colleagues having undergone peer review and participated in the peer-review process, and have also published in the journal. Because of the ease to check national credentials, the warning earlier of the potential for "national inbreeding" should be repeated. 


\section{RETROSPECTIVE DE-ACCREDITATION}

"When relatively new journals such as these quickly have single issues with dozens of articles and 'special issues' with dozens more, it's clear that there is something bad happening. In this case, researchers are using the quick, easy, and cheap publishing MCSER offers to get their quota of published articles in 'impact factor journals' for tenure and promotion. It's a breakdown of the academic system."

\section{MJSS and Beall assessments}

When Beall evaluated the publisher of the MJSS, he found the following problems in September 2014:87 Although "this publisher gives an address in Rome as its location, and although it might really have a presence there, the publisher is basically an Albanian operation" ${ }^{88}$ The editor attempted to deceive Beall by "telling [him] that the operation was being purchased by the German publisher De Gruyter". ${ }^{89}$ This turned out to be untrue. The articleprocessing charges for the three journals are relatively low at $\$ 200$ for a single paper or $\$ 280$ for two - with an additional volume discount if you publish two papers in the same issue of the journal. ${ }^{90}$ The number of issues and articles published is suspicious. Apart from the regular issues, multiple special issues of the journal appear annually: In 2013 there were 16 volumes (12 special editions), and in 2014 there were 23 issues. The MJSS also published 342 articles in a single issue (November 2014). ${ }^{9}$

It should be noted that the Scopus indexing services include MCSER's journals in their databases. Beall ${ }^{2}$ notes that this creates a veneer of respectability and that many academics are unaware of the bogus-impact factor companies, or they choose to pretend that they are real. ${ }^{93}$ This is cause for concern - as indexing should be one of the factors considered when evaluating a journal.

It is submitted that younger academics in South Africa would not necessarily have picked up on the issues discussed above and would not necessarily have found MJSS to be predatory. This makes the decision of DoHET manifestly unfair, as the process of assessment of a journal by academics is fraught with uncertainties and difficulties.

\section{Estoppel}

The aim of this article is also to determine whether the decision by DHET to retrospectively de-accredit the MJSS was lawful. Hypothetically, should a

${ }^{86}$ Beall http://scholarlyoa.com/2014/09/16/bogus-centre-provides-quick-and-cheap-publishing/.

87 Ibid.

88 In fact, in the instructions the publisher gives for wiring the article-processing fees, two bank accounts are given - one being a personal bank account.

89 Beall http://scholarlyoa.com/2014/09/16/bogus-centre-provides-quick-and-cheap-publishing/.

90 Beall calls this "wholesale publishing" and gives a number of examples of academics that did just that.

91 See: http://www.mcser.org/journal/index.php/mjss/issue/archive.

92 Beall Scholarly Open Access. Look Out for the Bogus Impact Factor Companies 2015 http://scholarlyoa.com/2013/08/06/bogus-impact-factor-companies/ (accessed 2015-04-22).

93 See discussion above. 
university or an academic sue DHET for the non-payment of subsidy for publications that appeared in the 2013 MJSS because DHET decided that the journal is not scholarly and no longer on the accredited lists - it is submitted that the doctrine of estoppel could be an applicable defence to deny DHET from enforcing the policy. In terms of estoppel:

"a person is precluded ... from denying the truth of a representation previously made by him ... to another person if the latter, believing in the truth of the representation, acted thereon to his or her prejudice".

Sonnekus ${ }^{95}$ notes that the elements for estoppel are: a legally relevant representation, blame, ${ }^{96}$ causation, detriment and maintainability. Estoppel is an equitable concept, which is aimed at preventing prejudice and injustice ${ }^{97}-$ that should be considered in light of the requirement of fairness to all parties. ${ }^{98}$

In this matter, it is submitted that a legally relevant representation was made by DHET, by publishing and distributing a list of accredited journals to all universities and academics ${ }^{99}$ - creating an unambiguous ${ }^{100}$ impression that the listed journals are scholarly and meet the DHET criteria for subsidy.

The blame that can be attributed to DHET is that it endorsed journals without determining their scholarliness beforehand. It is unsure when the complaints were raised with DHET about MJSS. But had there been a suspicion about these journals earlier than November $2014^{101}$ (when the deaccreditation decision was made), it is submitted that there would have been a legal duty on DHET to highlight its suspicions at the earliest opportunity - to ensure that academics refrain from acting to their detriment by attempting to publish in MJSS, and by warning them to submit their articles elsewhere.

However, the academics, believing in the truth of the representation that MJSS met the DHET criteria of scholarliness, acted on this representation by publishing in this journal. DHET could, however, potentially argue that the academics did not act reasonably by relying on the representation:

"A person who knows, or who is in law deemed to know because knowledge is imputed to him or her, that the real facts are not as stated in the representation made to such person, cannot be heard to say that he or she was induced to act to his or her prejudice on the faith of the representation?"

94 Rabie (updated by Daniels) "Estoppel” in Joubert WA (Founding Ed) The Law of South Africa IX 2nd ed (2005) par 652 (hereinafter "LAWSA IX Estoppel').

95 Sonnekus Rabie and Sonnekus Law of Estoppel in South Africa 3ed (2012) 48.

96 Sonnekus Estoppel 281 notes that blame, usually in the form of negligence, is required unless fairness, justice or the interests of commerce dictate otherwise.

97 LAWSA IX Estoppel par 652; Sonnekus Estoppel 2; Trust Bank v Eksteen 415H-415C; Raath "Publiekregtelike Estoppel, Billikheid en die Ontwikkeling van die Gemenereg: 'n Vonnisbespreking van Eastern Cape Provincial Government v Contractprops 25 (Pty) Ltd en Eastern Metropolitan Substructure v Peter Klein Investments (Pty) Ltd' 2005 Tydskrif vir Regswetenskap 146.

98 LAWSA IX Estoppe/ par 666; and Sonnekus Estoppe/ 3.

99 Sufficient if it was made public (LAWSA IX Estoppel par 660).

100 Sonnekus Estoppel 143, 146 - and the cases referred to.

101 See date of letter above. MJSS appeared on Beall's lists in September 2014.

102 LAWSA IX Estoppel par 656, and the cases referred to.

103 LAWSA IX Estoppel par 661. 
There is a duty on academics to take reasonable steps to avoid prejudice. ${ }^{104}$ This would mean that where academics knew or were deemed to know that MJSS is not a reputable, scholarly journal, the estoppel defence would not be successful. The test is objective: would a reasonable person have been misled? ${ }^{105}$ As discussed above, it is not necessarily obvious that the reasonable, especially younger academic would not have been misled on the information available.

DHET could raise questions about the causal connection between representation and the act of prejudice, ${ }^{106}$ and argue that the publication of the accredited lists was not the proximate cause of the prejudice ${ }^{107}-$ but rather the misconduct perpetrated by MJSS. ${ }^{108}$ Had the MJSS followed good scholarly guidelines, as they professed to do on their website, the problem of de-accreditation would not have arisen. It is, so the argument goes, the actions of MJSS that caused the prejudice and not the representation made by DHET. What exactly the misconduct of the MJSS was, is still uncertain as neither Beall nor DHET has set it out. Notwithstanding the technical issues raised by Beall, no formal evaluation is available about the scholarly attributes of all the actual articles in the journal.

With regard to the element of maintainability, estoppel is not allowed to operate in circumstances where it would result in an action which is not permitted by law. ${ }^{109}$ The courts have adopted the approach that:

"whenever the person whom it is sought to estop relies on a statutory illegality,
it is the duty of the court to determine whether it is in the public interest that the
representee should be allowed to plead estoppel, and that when doing so the
court will have regard to the mischief which the statute seeks to remedy, on the
one hand, and to the conduct of the parties, on the other hand".

DHET could argue that to pay a subsidy towards publication in a journal that is known not to meet its own criteria, would be an illegal or an ultra vires act. $^{11}$ However, Sonnekus ${ }^{112}$ notes that estoppel is possible if the representation relates to an internal policy or internal formalities - as was the case here.

Moreover, Raath ${ }^{113}$ acknowledges that, although South African administrative law has traditionally been unsympathetic towards the application of estoppel, the Constitution opened the door for a broader application: ${ }^{114}$

104 Sonnekus Estoppel 211.

105 Sonnekus Estoppel 102

106 LAWSA IX Estoppel par 664.

107 Sonnekus Estoppel 237 notes that the proximate-cause test serves to limit liability to instances where the loss was reasonably foreseeable.

108 LAWSA IX Estoppel par 664.

109 LAWSA IX Estoppel par 673; and Raath 2005 Tydskrif vir Regswetenskap 133, 145.

110 LAWSA IX Estoppel par 674, with reference to Trust Bank van Afrika Bpk v Eksteen 19643 SA 402 (A) 415-416C.

111 LAWSA IX Estoppel par 675.

112 Sonnekus Law of Estoppe/ 314, and the cases referred to.

113 Raath 2005 Tydskrif vir Regswetenskap 133.

114 Sonnekus Estoppe/ 323 notes that the perceived general principles excluding the reliance on estoppel against the State is not justified. 
"The Constitution has, however, altered the context in which the doctrine of estoppel by representation in terms of public law is to be viewed. There is now a constitutional imperative to ensure that the common law evolves within the framework of the Constitution consistent with the basic norms of the legal order that it establishes. It has been stated that instead of focusing solely upon the nature of the statutory duty, the court should be entitled to balance the competing interests at stake and take into account factors such as the prejudice to the party seeking to raise the estoppel. Instead of a blanket barrier to the raising of estoppel the common law should be developed to emphasise the equitable nature of the remedy, its function as a rule allocating the incidence of loss and flexibility in taking into account what is right, just and fair in all the circumstances."

Rabie $^{116}$ agrees that the "proper approach ... is that the court should balance the individual and public interests at stake and decide on that basis whether the operation of estoppel should be allowed in a specific case". Applying this approach, the following competing interests should be considered: the prejudice suffered by academics who bona fide followed the DHET lists and published quality research in the MJSS, the decision by DHET to retrospectively de-accredit the journal without notice and proper consultation, and the underlying public interest to subsidise only good scholarly work. It is submitted that the prejudice of academics could possibly outweigh public interest, in light of the actions of DHET.

Unfortunately, for a definitive answer, the matter will have to proceed to court. For a university or an academic (presuming both would have locus standi) ${ }^{117}$ to litigate against the DHET would be biting the proverbial hand that feeds you. Litigation is unlikely in light for the small number of academics involved, the cost of litigation and because universities were in principle consulted in the decision by participation in the ROE Panel. ${ }^{118}$

Apart from the arguments relating to estoppel, the constitutional aspects of the decision should now also be considered.

\section{Just administrative action}

Section 33(1) of the Constitution of the Republic of South Africa, 1996 demands administrative actions that are "lawful, reasonable and procedurally fair", and the right has been given context in the Promotion of Administrative Justice Act 3 of 2000 (PAJA).

Section 3(1) of PAJA requires that "administrative action which materially and adversely affects the rights or legitimate expectations of any person must be procedurally fair". ${ }^{119}$ This includes adequate notice, an opportunity to make representations - as well as the right to an appeal. ${ }^{120}$

115 Sonnekus Estoppel 318; LAWSA IX Estoppel par 675.

116 LAWSA IX Estoppel par 675, and the cases referred to.

117 S 38 of the Constitution. It is submitted that individual academics would have locus standi as DHET knew that they were intended to benefit from the policy. See Sonnekus Estoppel 338.

118 The representation on the ROE panel is, however, limited to only some universities.

119 Fairness depends on the circumstances of each case (s 2(a) PAJA).

120 S 2(b)(i), (ii) and (iv) of PAJA. 
Assuming that the acting DG had the power to make the decision, ${ }^{121}$ it is submitted that the decision by the DHET was an "administrative action" - as defined. ${ }^{122}$ In this scenario of the retrospective decision to de-accredit the MJSS, it materially and adversely affected the legitimate expectations ${ }^{123}$ of the universities and respective academics, as the de-accreditation directly resulted in a loss of subsidy. The legitimate expectation is found in the express promise by the Ministry of Education Measurement of Research Output $^{124}$ to pay subsidy for an accredited output, the inclusion of the IBSS list as determining accreditation, the appearance of MJSS on that official list, and the historical application of the subsidy policy. Universities can surely expect DHET to honour its own policy, and own chosen lists.

In addition, because the decision was made retrospectively to 2013 publications, the decision cannot be regarded as procedurally fair - as there was no adequate notice given to universities and academics, and also no right to respond and no appeal.

"The prohibition of retrospective administrative measures is based on the principle of legal certainty which, in turn, derives from the rule of law."

In the words of De Ville, ${ }^{126}$ the decision by DHET to de-accredit, "purports to change the legal consequences of events that occurred in the past". It flies in the face of the principle against retrospectively, a principle that is historically based on the presumption that the legislature does not wish to interfere with vested rights - an argument used in the courts to have delegated legislation declared invalid. ${ }^{127}$ This decision on MJSS changed the contents of the policy - a policy upon which reliance was placed by academics.

This scenario in casu is comparable to the case of Premier, Province of Mpumalanga v Executive Committee of the Association of Governing Bodies of State-Aided Schools: Eastern Transvaal. ${ }^{128}$ In this matter, the decision to retrospectively change the policy for bursary funding was regarded as procedurally unfair and invalid. ${ }^{129}$ The procedural and substantive aspects of the legitimate expectation were entwined, but as the scheme had been in

121 Her appointment seems to fall within the National Plan for Higher Education and there is no reason to prima facie believe that she did not have the authority to do so, although her appointment and the scope of her powers cannot be verified without the departmental information. This is not available to the author, and falls outside the scope of this article.

$122 \mathrm{~S} 1(\mathrm{a})(\mathrm{ii})$ of PAJA.

123 The principle of legitimate expectation is settled law in South Africa, since Administrator, Transvaal v Traub 1989 (4) SA 731 (A). See, also, Claude Leon Ltd v City Council of Germiston 19953710 (W); Hoexter Administrative law in South Africa 2ed (2013) 421 onwards; and Quinot Administrative Law. Cases and Materials (2008) 470-495.

124 Administrator, Transvaal v Traub supra 756. See, also, Burns and Beukes Administrative Law under the South African Constitution, 1996 (2006) 218.

125 De Ville Judicial Review of Administrative Action in South Africa (2005) 191.

126 Ibid.

127 lbid.

1281999 (2) SA 91 (CC) par 41; and De Ville Judicial Review 192.

129 Par 42; De Ville Judicial Review 192; Quinot Administrative Law 490; and Burns and Beukes Administrative Law 219. 
existence for many years, it would be unfair to change it without adequate notice. ${ }^{130}$

Although DHET might argue that an opportunity was given to make representations, by consulting with the ROE panel, it is submitted that this was inadequate - as the affected academics were not given notice or any opportunity to make representations, or to explain or defend the publications in the MJSS, which may (or may not) turn out to be peer-reviewed and scholarly. In addition, all public universities affected by the de-accreditation decision were not represented on the panel.

As mentioned above, although the decision could be taken on judicial review in principle ${ }^{131}$ - on the basis of unfair procedure, unreasonableness, ${ }^{132}$ being unconstitutional or unlawfulness ${ }^{133}$ - it is unlikely that a university or an academic would do so.

\section{CONCLUSION}

DHET has always had a clear policy for subsidising research: publication in an accredited journal will lead to the payment of subsidy to the university, and usually, indirectly to the academic. The de-accreditation of MJSS from the official DHET list of accredited journals, because it was an online predatory journal, has created much uncertainty about the application of a similar policy in future. The decision destabilised DHET's own policy, and it is argued that DHET acted unlawfully and unfairly. Not only should it be estopped from denying the truth of its own representation, its decision to retrospectively change its policy without adequate notice or proper opportunity for representations, is unconstitutional based on the legitimate expectation of the universities and academics - created by the DHET's policies and practice.

This article sets out the landscape relating to the online access of scholarly research - that has grown exponentially in recent times. With the positive consequences of instant and cheap availability that it brings, this form of publication also opens the door to unscrupulous publishers. Academics should be vigilant about choosing an appropriate journal to publish their research and do some appropriate due diligence. Possible criteria that could be used for assessing suitable new journals as targets for publishing in, have been discussed and listed. This is, however, a process which is fraught with uncertainties, difficulties and value judgments - that young academics are illequipped to make, because of their inexperience. Many predatory publishers deliberately set out to scam academics in the name of financial profits, and in the digital age, academics need to be aware of this.

130 Par 38-41. See, also, Hoexter Administrative Law 422. This outcome is in line with the decisions of the European Court of Justice (Quinot Administrative Law 490 fn 13).

131 S 6 of PAJA.

${ }^{132} \mathrm{~S} 6(\mathrm{~h})$ of PAJA.

133 De Ville Judicial Review 192 argues that "retrospective administrative action without legislative authorisation could be regarded as otherwise unconstitutional or unlawful" in terms of $s$ (2) of PAJA. 